\title{
Clinical correlates of treatment adherence and insight in patients with schizophrenia
}

\section{Şizofreni hastalarında tedavi uyumu ve içgörünün değerlendirilmesi}

\author{
Ahmet Kokurcan ${ }^{1}$, Hasan Karadağ ${ }^{1}$, Selma Ercan Doğu ${ }^{1}$, Funda Erdi ${ }^{1}$, Sibel Örsel ${ }^{1}$
}

\begin{abstract}
Aim: The aim of this study was to assess clinical correlates of the treatment adherence and insight in patients with schizophrenia.

Methods: That cross-sectional study included 229 outpatients with schizophrenia who were admitted to the Psychiatry Outpatient Clinic of Health Sciences University Dışkapı Yıldırım Beyazıt Training and Research Hospital. All participants were administered a socio-demographic form, Morisky Medication Adherence Questionnaire, Schedule for Assessing the three components of insight, Brief Psychiatric Rating Scale, Positive and Negative Symptoms Rating Scale, Calgary Depression Scale for Schizophrenia, and Global Assessment of Functioning Scale. Collected data were analyzed with descriptive statistics, Pearson Correlation Analysis, and logistic regression analysis.

Results: Poor treatment adherence was associated with male gender, lower insight level, more severe psychotic symptoms, and lower functionality level. The insight score was negatively correlated with the severity of psychotic symptoms, duration of the disorder, and mean antipsychotic dose; but positively correlated with advanced age of onset, and higher functionality level. The logistic regression analysis revealed that functionality level was more predictive on poor medication adherence.

Conclusion: Poor treatment adherence and lower insight level were closely associated with more severe clinica symptoms and lower functionality level. It was noteworthy that adherence and insight levels both showed a high predictivity for wellbeing of the patients. Therefore, psychotherapeutic interventions should be implemented to increase treatment adherence and insight in schizophrenia even if the psychotic symptoms show resistance. Further research is needed to clarify clinical associations of the treatment adherence and insight level in patients with schizophrenia.
\end{abstract}

Keywords: treatment adherence, schizophrenia, insight

\section{Öz}

Amaç: Bu çalışmanın amacı şizofreni hastalarında tedaviye uyumu ve içgörü ile ilişkili klinik değişkenler değerlendirmektir.

Yöntemler: Kesitsel nitelikteki bu çalışmaya Sağlık Bilimleri Üniversitesi Dışkapı Yıldırım Beyazıt Eğitim ve Araştırma Hastanesi Psikiyatri Polikliniği'ne başvuran 229 şizofreni hastası dahil edildi. Tüm katılımcılara sosyodemografik veri formu, Morisky Tedaviye Uyum Ölçeği, İçgörünün Üç Bileșenini Değerlendirme Ölçeği, Kısa Psikiyatrik Değerlendirme Ölçeği, Pozitif ve Negatif Belirtileri Değerlendirme Ölçeği, Calgary Şizofrenide Depresyon Ölçeği ve İşlevselliğin Genel Değerlendirilmesi Ölçeği uygulanmıştır. İstatiksel analizde tanımlayıc analizler, Pearson Korelasyon Analizi ve lojistik regresyon analizi kullanıldı.

Bulgular: Şizofrenide düşük tedavi uyumu bulunması erkek cinsiyet, düşük içgörü düzeyi, yüksek psikotik belirt şiddeti ve düşük işlevsellik düzeyi ile ilişkili bulundu. İç̧örü düzeyi ise psikotik belirti şiddeti, hastalığın süres ve ortalama antipsikotik ilaç dozu ile negatif korelasyon gösterirken; geç başlangıç yaşı ve yüksek işlevsellik düzeyi ile pozitif korelasyon gösterdi. Lojistik regresyon analizinde ise işlevsellik düzeyinin düşük tedavi uyumunu öngörmede daha etkili olduğu belirlendi.

Sonuç: Düşük tedavi uyumu ve içgörü düzeyi yüksek klinik belirti şiddetiyle ve düşük işlevsellik düzeyiyle güçlï korelasyon gösterdi. Tedavi uyumu ve içgörü düzeyi hastaların iyilik durumu üzerinde önemli prediktif faktörler olarak saptandı. Bu nedenle psikotik belirtiler dirençli olsa dahi şizofreni hastalarında tedavi uyumu ve içgörüyü arttırmaya yönelik psikososyal tedaviler uygulanmalıdır. Şizofreni hastalarında tedavi uyumu ve içgörü düzeyi ile ilișkili klinik değişkenlerin daha iyi anlaşılması için gelecekte yapılacak çalıșmalar önemli olacaktır.

Anahtar Kelimeler: tedavi uyumu, şizofreni, içgörü
1 Department of Psychiatry, Health Sciences University Dışkapı Yıldırım Beyazıt Training and Research Hospital, Ankara, Turkey.

in

AK: 0000-0002-5763-2506

HK: 0000-0001-9487-3424

SED: 0000-0003-3276-8041

FE: 0000-0001-9487-3424

SÖ: 0000-0003-0184-7038

Ethics Committee Approval: The study was approved by Diskapi Yildirim Beyazit Training and Research Hospital (06.11.2017-4210)

Etik Kurul Onayı: Bu çalışma Dışkapı Yıldırım Beyazıt Eğitim ve Araştırma Hastanesi Etik Kurulu'ndan onay almıștır (06.11.2017-4210).

Conflict of Interest: No conflict of interest was declared by the authors.

Çıkar Çatışması: Yazar çıkar çatışması bildirmemiștir.

Financial Disclosure: The authors declared that this study has received no financial support. Finansal Destek: Yazarlar bu çalışma için finansal destek almadıklarını beyan etmişlerdir.

Geliş Tarihi / Received: 09.04.2020

Kabul Tarihi / Accepted: 08.11.2020

Yayın Tarihi / Published: 15.12.2020

Sorumlu yazar / Corresponding author:

Ahmet Kokurcan

Adres/Address: Şehit Ömer Halisdemir Street Dıskapı Yıldırım Beyazıt Training and Research Hospital Altındağ/Ankara, Turkey.

e-mail: ahmetkokurcan @ gmail.com

Tel/Phone: +90 3123186612

Copyright $(\mathrm{C}$ ACEM 


\section{Introduction}

Schizophrenia is a chronic disorder and shows poor clinical outcomes. One of the main reasons affecting on the clinical course of schizophrenia is poor treatment adherence. Many patients with schizophrenia drop out the medication in less than one year, and full adherence to treatment in patients with schizophrenia is not common [1]. Treatment adherence is defined as regular use of the drugs and compatibility with implemented suggestions of the healthcare staff [2]. Good treatment adherence is a necessity for the patients with schizophrenia to maintain improvement, however, there is a high rate of poor medication adherence in schizophrenia patients. Poor medication adherence in schizophrenia is associated with more relapses, increased number of hospitalizations, and poor clinical course [3].

Clinical course of schizophrenia is affected by several clinical factors, such as characteristics of the disorder, comorbid psychiatric disorders, and medication adherence [4]. Insight level is also a predictive factor on clinical course of schizophrenia [5]. Insight is basically defined as awareness of the disorder and signs of exacerbation. The insight concept also includes ability to interpret clinical symptoms as pathological and acceptance of the treatment [6,7]. A recent study assessed the impact of psychoeducation on knowledge level about the disorder and insight in patients with schizophrenia. That study revealed that psychoeducation did not have a significant impact on insight but provided a significant improvement on clinical symptoms [8]. Even if better insight level is not improved by the clinical interventions, the interventions might improve clinical outcomes in schizophrenia patients $[8,9]$.

Poor treatment adherence and low insight level often show a good clinical association in schizophrenia; however, poor medication adherence can be found in patients with good clinical insight $[9,10]$. Besides that, some patients with lower insight can be provided an adequate antipsychotic treatment [11]. Taken together, there are some differences between clinical associations of the medication adherence and insight. As both are major predictive factors on clinical course of schizophrenia, it is important to clarify clinical associations of the treatment adherence and insight in schizophrenia. A better understanding on the clinical associations of those two variables might improve clinical outcomes and therefore it was aimed to assess correlates of the treatment adherence and insight in patients with schizophrenia.

\section{Material and methods}

This study was carried out in Dışkapı Yıldırım Beyazıt Training and Research Hospital. The patients aged between 18 and 60 with the diagnosis of schizophrenia according to Diagnostic and Statistical Manual of Mental Disorders, 5th edition (DSM-5) who applied to the outpatient Psychiatry Clinic of the Hospital between December 2017 and June 2018 were enrolled into the study [12]. The patients with remission and partial remission were included and patients who are not in remission/ partial remission $(n=21)$ were not got involved. In addition, those with organic brain disorders $(n=8)$, neurodevelopmental disorders $(n=2)$, and alcohol or substance use disorders $(n=5)$ were excluded. Therefore, 229 patients were included as participants. The study was carried out in compatibility to the Declaration of Helsinki. Written informed consents were obtained from all of the participants, and Ethical Commission of the Dışkapı Training and Research Hospital approved the study (06.11.2017-4210).

\section{Instruments}

Brief Psychiatric Rating Scale (BPRS): The BPRS is used to evaluate general symptom severity in patients with schizophrenia. It was developed by Overall and Gorham in 1961 [13]. It is an 18-item Likert scale, and all items are scored between 1 (absent) and 7 (severe) points. Its Turkish validity and reliability were made by Soykan et al. in 1989 [14].

Scale for the Assessment of Negative Symptoms (SANS): The SANS measures negative symptom severity such as anhedonia, avolition, and the items are rated from 0 to 5 . It was developed by Andreasen in 1990 and its Turkish validity and reliability study was conducted by Erkoç et al. in $1991[15,16]$.

Scale for the Assessment of Positive Symptoms (SAPS): The SAPS assesses severity of positive symptoms like hallucinations, delusions, and the total score of the SAPS is 170. It was developed by Andreasen in 1990 and its Turkish validity and reliability study was conducted by Erkoç et al. in 1991 [15, 17].

Morisky 8-item medication adherence questionnaire (MMAS-8): Good medication adherence is a key factor on the treatment response to the antipsychotics in schizophrenia. There is a high rate of low treatment adherence in patients with schizophrenia, and low adherence is one of the most important reasons of poor clinical course in schizophrenia [3]. The MMAS8 assesses if there is a poor compliance to medication intake because of forgetfulness, carelessness or stopping the drug voluntarily $[2,7]$. It is a self-rated questionnaire consisting of eight questions and first seven elements of the questionnaire include yes/no answers while the eighth element has five answers [18]. When the answer indicates a negative adherence issue, a score of 1 is recorded. A score of 3 and higher on the MMAS- 8 indicate a poor medication adherence in patients with schizophrenia while a score of 2 and lower on the scale show a good medication adherence. It was developed by Morisky et al. [18] and Turkish validity and reliability study was performed by Hacihasanoglu Asslar et al. in 2014 [18, 19].

Schedule for Assessing Insight Scale (SAI): The SAI is a likert scale and it is used to measure the insight level of the patients. Its items are rated from 0 to 2 and it has 7 items. It was developed by David et al. [20] and its Turkish validity and reliability study was made by Arslan et al. in 2000 [20, 21].

Calgary Depression Scale for Schizophrenia (CDSS): The CDSS is a nine-item structured interview scale, and it is used to measure the depression level within last two weeks in patients with schizophrenia. It was developed for the assessment of depressive symptoms by Addington et al. [22]. Turkish validity and reliability study were made by Oksay et al. in 2000 [22, 23].

Global Assessment of Functioning Scale (GAF): Functionality in schizophrenia is defined as the ability to work full-time, to have good social relationships and communication skills, and being able to accomplish daily tasks by himself/herself in society. The GAF scale is a widely used scale for assessment of the functionality level of the patients with schizophrenia and it was used in the present study. The scale is scored between 0 to 100 , and it was developed by Endicott et al. [24] and it was included in Diagnostic and Statistical Manual of Mental Disorders (4th ed.; DSM-IV) [24, 25].

\section{Statistical Analysis}

Clinical data were presented as mean \pm standard deviation (SD). Demographic and clinical characteristics of the patients with good and poor adherence were compared with descriptive statistics. Pearson correlation analysis was used to assess clinical correlations of the treatment adherence and insight level. Logistic regression analysis was carried out to determine which clinical variables were more predictive on the treatment 
adherence. The statistical analyses were carried out with the Statistical Package for the Social Sciences (SPSS) version 21. All probability values ( $\mathrm{p}$ values) were computed as two - sided, and $\mathrm{p}<0.05$ was considered statistically significant.

\section{Results}

The sample included 229 patients with a mean age of $38.96 \pm 10.36$ years, and $30 \%(n=69)$ of the sample was female while $28 \%(n=64)$ of the individuals were married. About $24 \%$ $(\mathrm{n}=55)$ of the patients was classified as having poor medication adherence according to the MMAS- 8 scale while $76 \%(n=174)$ of the patients showed good medication adherence. The poor adherence rate was $13 \%$ in female patients, whereas it was $29 \%$ in male patients. The difference in adherence rate between the male and female was significant $(p<0.05)$. Mean onset age of the disorder was $23.50 \pm 6.41$ years, and mean duration of the disorder was $15.49 \pm 6.41$ years in the patients with good adherence. On the other hand, they were $21.91 \pm 5.09$ and $15.73 \pm 8.49$ years in the poor adherence group. Comparison of the onset age, duration of the disorder, and CDSS score did not show a significant difference between the groups ( $p>0.05$ ). In addition, no significant difference was seen between the two groups in terms of age, marital status, and education level ( $p>0.05$ ). Poor treatment adherence was associated with male gender, more severe BPRS, SANS, SAPS scores, and lower functionality level $(\mathrm{p}<0.05)$. The BPRS scores were $26.45 \pm 5.86$ and $21.97 \pm 8.27$ in poor and good adherence groups, respectively $(\mathrm{p}<0.05)$. Also, the patients with poor adherence demonstrated more severe positive and negative symptoms compared to those with good adherence (SAPS: 32.82 $\pm 6.85,28.16 \pm 7.85$; SANS: $32.51 \pm 6.28,28.50 \pm 7.06$, respectively, $\mathrm{p}<0.05)$. However, mean equivalent dose of chlorpromazine and severity of the depressive symptoms did not show a significant difference between the patients with poor and good adherence ( $p>0.05)$. Table 1 shows the comparison between the two groups in terms of the main sociodemographic and clinical characteristics.

The SAI score was higher in good adherence group and the difference between two groups was significant $(10.03 \pm 1.72$, $9.11 \pm 1.44$, respectively, $\mathrm{p}<0.05)$. Age, gender, marital status, and education level were not associated with the insight level ( $\mathrm{p}>$ $0.05)$. The SAI score was negatively correlated with duration of the disorder and mean antipsychotic dose; but positively correlated with advanced age of onset and higher GAF score. The severity of BPRS, SAPS, and SANS symptoms were all negatively correlated with the SAI score $(r=-0.481, r=-0.402, r=-$ 0.413 , respectively, $\mathrm{p}<0.01$ ). The correlation of the insight level with clinical characteristics of the patients is shown in Table 2.

Logistic regression analysis was carried out to determine which clinical variables were more predictive on the treatment adherence. The logistic regression analysis including the SANS, SAPS, SAI, and GAF scales revealed that functionality level (Odds ratio $=4.158, \mathrm{p}=0.041, \mathrm{~B}=0.065$ ) was more predictive on poor adherence. The logistic regression analysis is demonstrated in Table 3.

\section{Discussion}

Nearly one-fourth of the patients with schizophrenia showed poor medication adherence. Sociodemographic variables did not show a significant difference between the poor and good adherence groups. Severity of clinical symptoms was related with poor treatment adherence and other variables associated with poor adherence were low functionality level and male gender. The patients with good medication adherence had higher insight level compared to those with poor adherence. Insight level was also not associated with the sociodemographic variables.
Table 1. Comparison of the sociodemographic and clinical characteristics between the patients with good and poor treatment adherence.

\begin{tabular}{|c|c|c|c|c|}
\hline & $\begin{array}{c}\text { Patients with } \\
\text { good } \\
\text { adherence } \\
(\mathrm{n}=174)\end{array}$ & $\begin{array}{l}\text { Patients with } \\
\text { poor adherence } \\
\quad(\mathrm{n}=55)\end{array}$ & $\mathrm{p}$ & \\
\hline Age (year) ${ }^{a}$ & $39.30 \pm 10.11$ & $37.89 \pm 11.15$ & 0.177 & $\mathrm{~F}=1.832$ \\
\hline Gender $^{\mathrm{b}}$ & & & $0.011^{*}$ & $\mathrm{x}^{2}=6.517$ \\
\hline Female & $60(34.5)$ & $9(16.4)$ & & \\
\hline Male & $114(65.5)$ & $46(83.6)$ & & \\
\hline Marital Status ${ }^{\mathrm{b}}$ & & & 0.245 & $\mathrm{x}^{2}=1.350$ \\
\hline Single or Seperated & $122(70.1)$ & $43(78.2)$ & & \\
\hline Married & $52(29.9)$ & $12(21.8)$ & & \\
\hline Education level ${ }^{\mathrm{b}}$ & & & 0.527 & $\mathrm{x}^{2}=2.227$ \\
\hline Primary school or & & & & \\
\hline lower & $53(30.5)$ & $12(21.8)$ & & \\
\hline Middle school & $45(23)$ & $19(34.5)$ & & \\
\hline High school & $57(32.8)$ & $18(32.7)$ & & \\
\hline University & $19(10.9)$ & $6(10.9)$ & & \\
\hline Onset age ${ }^{a}$ & $23.50 \pm 6.41$ & $21.91 \pm 5.09$ & 0.094 & $\mathrm{~F}=1.768$ \\
\hline $\begin{array}{l}\text { Duration of } \\
\text { schizophrenia }^{a}\end{array}$ & $15.49 \pm 6.41$ & $15.73 \pm 8.49$ & 0.850 & $\mathrm{~F}=0.084$ \\
\hline $\begin{array}{l}\text { Number of } \\
\text { hospitalizations }^{\mathrm{a}}\end{array}$ & $2.75 \pm 1.86$ & $3.44 \pm 2.25$ & 0.057 & $\mathrm{~F}=2.271$ \\
\hline SANS $^{\mathrm{a}}$ & $28.50 \pm 7.06$ & $32.51 \pm 6.28$ & $0.000 *$ & $\mathrm{~F}=0.743$ \\
\hline SAPS $^{a}$ & $28.16 \pm 7.85$ & $32.82 \pm 6.85$ & $0.000 *$ & $F=2.606$ \\
\hline $\mathrm{BPRS}^{\mathrm{a}}$ & $21.97 \pm 8.27$ & $26.45 \pm 5.86$ & $0.000 *$ & $\mathrm{~F}=8.908$ \\
\hline $\mathrm{GAF}^{\mathrm{a}}$ & $57.24 \pm 7.06$ & $52.36 \pm 5.92$ & $0.000 *$ & $\mathrm{~F}=1.459$ \\
\hline $\mathrm{CDSS}^{\mathrm{a}}$ & $1.76 \pm 1.90$ & $1.71 \pm 1.23$ & 0.906 & $\mathrm{~F}=0.143$ \\
\hline $\mathrm{SAI}^{\mathrm{a}}$ & $10.03 \pm 1.72$ & $9.11 \pm 1.44$ & $0.000 *$ & $\mathrm{~F}=2.087$ \\
\hline
\end{tabular}

Data; number of cases (percentage). \# Mean \pm S.D. a Independent sample t-test, b Chi-square test for independence, $\mathrm{p}<0.05 *$ Scale for the Assessment of Positive and Negative Symptoms (SAPS/SANS), Brief Psychiatric Rating Scale (BPRS), Calgary Depression Scale for Schizophrenia (CDSS), Schedule for Assessing the three components of insight (SAI), and Global Assessment of Functioning Scale (GAF).

Although onset age of schizophrenia and duration of the disorder were not related with treatment adherence, lower insight level was associated with earlier age of onset and longer duration of schizophrenia. Severity of positive, negative, and general psychiatric symptoms showed a moderate negative correlation with insight level. Functionality level demonstrated the highest correlation with insight level, and it was found to be more predictive on poor treatment adherence.

Table 2. Correlation of the insight level with clinical characteristics of the patients.

\begin{tabular}{lcc} 
Variables & $\mathrm{p}$ & $\mathrm{r}$ \\
\hline Age & 0.402 & -0.056 \\
Onset age & 0.017 & 0.157 \\
Duration of schizophrenia & 0.009 & -0.172 \\
Number of hospitalizations & 0.223 & -0.095 \\
SANS & $<0.000$ & -0.413 \\
SAPS & $<0.000$ & -0.402 \\
BPRS & $<0.000$ & -0.481 \\
CDSS & 0.305 & 0.109 \\
GAF & $<0.000$ & 0.541 \\
\hline
\end{tabular}

Pearson Correlation Analysis, $\mathrm{p}<0.05 *$ SAPS: Scale for the Assessment of Positive Symptoms, SANS: Scale for the Assessment of Negative Symptoms, BPRS: Brief Psychiatric Rating Scale, CDSS: Calgary Depression Scale for Schizophrenia, SAI: Schedule for Assessing the three components of insight, GAF: Global Assessment of Functioning Scale.

The rate of poor treatment adherence was $24 \%$ in patients with schizophrenia, and there is a great need to plan more preventive strategies on poor adherence. Treatment adherence consists of adherence to medical treatment and compliance to suggestions of the medical team. Our study assessed medication adherence and it is the most researched issue of treatment adherence. As known, maintenance of recovery can be provided with good adherence to medical therapy in all chronic disorders, however, poor adherence is common in chronic disorders [26,27]. Medication adherence is the core of the schizophrenia treatment 
and poor treatment adherence in nearly one-fourth of the patients demonstrated a substantial problem in the present study [5]. On the other hand, our study did not assess compatibility with suggestions of the healthcare staff, which is more complex part of the adherence issue.

Table 3. Logistic regression analysis for variables associated with poor adherence.

\begin{tabular}{lcccc} 
Variables & Exp (B) & $\begin{array}{c}\text { Standard } \\
\text { Error }\end{array}$ & Wald & p value \\
\hline SANS & 0.011 & 0.035 & 0.100 & 0.752 \\
SAPS & 0.035 & 0.030 & 1.423 & 0.233 \\
GAF & -0.065 & 0.032 & 4.158 & 0.041 \\
SAI & -0.146 & 0.017 & 1.566 & 0.211 \\
\hline
\end{tabular}

SAPS: Scale for the Assessment of Positive Symptoms, SANS: Scale for the Assessment of Negative Symptoms, BPRS: Brief Psychiatric Rating Scale, CDSS: Calgary Depression

Scale for Schizophrenia, SAI: Schedule for Assessing the three components of insight, GAF: Global Assessment of Functioning Scale.

No significant differences were seen in terms of marital status and education level between the patients with good and poor adherence. It was not surprising as there was no significant relationship between treatment adherence and those variables in most of the previous studies [1,6]. There was no significant relationship between age and treatment adherence in the present study, however, some studies found that nonadherence was significantly associated with younger age [28]. Cultural factors and higher family support in our country might have provided a better medication adherence in younger age. In addition, the poor adherence rate was $13 \%$ in female patients, whereas it was $29 \%$ in male patients. The finding of higher rate of poor adherence in male patients was shown in some previous studies [29]. It was suggested that female patients tend to have more enduring and connected social relationships, and thus, they showed better treatment adherence in those studies [29,30]. In addition, seeking help from others was more common in female patients compared to male patients.

In terms of clinical variables, poor treatment adherence was associated with more severe positive, negative, and general psychiatric symptoms. Lower functionality level was related with poor adherence while onset age of schizophrenia and duration of the disorder did not show a significant association with medication adherence. Those findings of more severe clinical symptoms in the patients with poor medication adherence confirmed the results of previous studies [6,11]. As shown in previous studies, poor treatment adherence is a substantial variable on the clinical course of schizophrenia and causes relapses in many patients with schizophrenia [31]. On the other hand, there was no significant difference in severity of the depressive symptoms between the patients with poor and good treatment adherence. This finding indicated that severity of the depressive symptoms was not associated with psychotic symptom severity, and affective symptoms showed a distinct clinical pattern in patients with schizophrenia [10].

Age, gender, marital status, and education level were not associated with the insight level, and that finding was consistent with most of the previous studies $[7,8]$. There was a significant difference in insight level between the patients with poor and good adherence, and the good adherence group had higher insight level. In addition, the severity of positive, negative, and general psychiatric symptoms was all negatively correlated with the insight score. Therefore, the present study supported the approval that insight level is a predictive factor on treatment adherence, and closely associated with the severity of clinical symptoms [32]. Many previous studies reported that OCD patients with poor insight show poor treatment adherence, more resistant symptoms, and more severe clinical symptoms [33]. Furthermore, duration of OCD was found to be related with lower insight level in several studies, and the insight level was also negatively correlated with the duration of the disorder in the present study [34]. Therefore, it can be suggested that there is a close similarity between OCD and schizophrenia regarding the relationship between lower insight level and clinical course of the patients.

The insight level was negatively correlated with mean duration of the disorder and mean antipsychotic dose. As schizophrenia causes a gradual cognitive impairment during the clinical course, duration of the disorder and longer antipsychotic use might have affected the insight level $[5,35]$. Besides that, it can be suggested that low insight is also predictive on mean antipsychotic dose in schizophrenia, considering its predictivity on the clinical severity. The insight level showed a positive correlation between advanced onset age and higher functionality level of the patients. That finding was also similar with previous studies $[7,8]$.

The present study has some limitations. It was designed as a cross-sectional study and the clinical associations cannot be presented in a causal relationship. Additionally, effectiveness of the psychotherapeutic interventions on the treatment adherence and insight were not assessed due to the cross-sectional design. Treatment adherence was not assessed in a particular period and was not confirmed with a blood sample test.

It was noteworthy that medication adherence and insight both showed a high predictivity for functionality of the patients. Furthermore, functionality level was found more predictive on treatment adherence compared to severity of positive and negative symptoms. Therefore, psychotherapeutic interventions should be implemented to increase treatment adherence and insight in schizophrenia even if the psychotic symptoms show resistance [31]. Finally, a complete treatment adherence and full insight level in patients with schizophrenia cannot be achieved, nevertheless, improving treatment adherence and insight might provide better clinical and functional outcomes [36]. Future studies are needed to clarify clinical correlates of the treatment adherence and insight in patients with schizophrenia.

\section{References}

1. García-Cabeza I, Díaz-Caneja CM, Ovejero M, de Portugal E. Adherence, insight and disability in paranoid schizophrenia. Psychiatry Res. 2018;270:274-80.

2. Modanloo M. The challenge of increasing adherence in schizophrenia: Focusing future research on changing attitudes of patients. Asian J Psychiatr. 2018;36:28.

3. Xu DR, Gong W, Gloyd S, Caine ED, Simoni J, Hughes JP, et al. Measuring adherence to antipsychotic medications for schizophrenia: Concordance and validity among a community sample in rural China. Schizophr Res. 2018;201:307-14.

4. Ogawa Y, Fukuhara K, Tanaka H, Nagata Y, Ishimaru D, Nishikawa T. Insight Into Illness and Defense Styles in Schizophrenia. J Nerv Ment Dis. 2019;207:815-19.

5. Settem VVJ, Karanadi H, Praharaj SK. Cognitive deficits, depressive symptoms, insight, and medication adherence in remitted patients with schizophrenia. Indian J Psychiatry 2019;61:335-41.

6. Browne J, Nagendra A, Kurtz M, Berry K, Penn DL. The relationship between the therapeutic alliance and client variables in individual treatment for schizophrenia spectrum disorders and early psychosis: Narrative review. Clin Psychol Rev. 2019;71:51-62.

7. Belvederi Murri M, Amore M. The Multiple Dimensions of Insight in Schizophrenia-Spectrum Disorders. Schizophr Bull. 2019;45:27783.

8. Tessier A, Boyer L, Husky M, Baylé F, Llorca PM, Misdrahi D. Medication adherence in schizophrenia: The role of insight, therapeutic alliance and perceived trauma associated with psychiatric care. Psychiatry Res. 2017;257:315-21.

9. Kane JM, Agid O, Baldwin ML, Howes O, Lindenmayer JP, Marder $\mathrm{S}$, et al. Clinical Guidance on the Identification and Management of Treatment-Resistant Schizophrenia. J Clin Psychiatry 2019;80. pii: 18com12123. doi: 10.4088/JCP.18com12123. 
10. Arraras JI, Ibañez B, Pereda N, Iribarren S, Basterra I. The association of clinical insight and depression with quality of life in schizophrenia. Psychiatry Res. 2019;279:350-52.

11. Dondé C, Senn M, Eche J, Kallel L, Saoud M, Brunelin J. Wellinformed but not aware: The P.A.C.T. ${ }^{\circledR}$ psychoeducation program for schizophrenia improves knowledge about, but not insight into, the illness. Asian J Psychiatr. 2019;46:15-8.

12. American Psychiatric Association. Schizophrenia spectrum and other psychotic disorders. In: Carpenter WT, editor. Diagnostic and statistical manual of mental disorders (5th ed.). Arlington, VA: American Psychiatric Association; 2013.p.87-123.

13. Overall JE, Gorham DR. The brief psychiatric rating scale (BPRS): recent developments in ascertainment and scaling. Psychopharmacol Bull. 1988;24:97-9.

14. Soykan C. Institutional differences and case typicality as related to diagnosis system severity, prognosis and treatment Access and utilization (dissertation). Ankara: Middle East Technical University Psychology Department, 1989.

15. Andreasen NC. Methods for assessing positive and negative symptoms. Mod Probl Pharmacopsychiatry 1990;24:73-88.

16. Erkoç Ş, Arkonaç O, Ataklı C, Özmen E. Negatif Semptomları Değerlendirme Ölçeğinin güvenilirliği ve geçerliliği. Düşünen Adam. 1991;4:16-9.

17. Erkoç Ş, Arkonaç O, Ataklı C, Özmen E. Pozitif Semptomları Değerlendirme Ölçeğinin güvenilirliği ve geçerliliği. Düşünen Adam. 1991;4:20-4.

18. Morisky DE, Ang A, Krousel-Wood M, Ward HJ. Predictive validity of a medication adherence measure in an outpatient setting. J Clin Hypertens. 2008;10:348-54.

19. Hacıhasanoğlu Aşılar R, Gözüm S, Capık C, Morisky DE. Reliability and validity of the Turkish form of the eight-item Morisky medication adherence scale in hypertensive patients. Anadolu Kardiyol Derg. 2014;14:692-700.

20. David A, Buchanan A, Reed A. Assessment of insight in psychosis. Br J Psychiatry. 1992;161:599-602.

21. Arslan S, Günay Kılıç B, Karakılıç H. İçgörünün Üç Bileșenini Değerlendirme ölçeği güvenirlik ve geçerlik çalışması. Türkiye'de Psikiyatri. 2000;3:17-24.

22. Addington D, Addington J, Schissel B. A depression rating scale for schizophrenics. Schizophr Res. 1990;3:247-51.

23. Oksay SE, Aksaray G, Kaptanoğlu C, Bal C. Calgary Depresyon Ölçeğinin şizofreni hastalarında geçerlik ve güvenirlilik çalışması. Türk Psikiyatri Dergisi. 2000;11: 278-84.

24. Endicott J, Spitzer RL, Fleiss JL, Cohen J. The Global Assessment Scale: A Procedure for Measuring Overall Severity of Psychiatric Disturbance. Arch Gen Psychiatry. 1976;33:766-71.

25. American Psychiatric Association. Diagnostic and statistical manual of mental disorders: DSM-IV. Washington, DC: American Psychiatric Association; 1994. p.34.

26. Sampaio R, Azevedo LF, Dias CC, Castro Lopes JM. Non-Adherence to Pharmacotherapy: A Prospective Multicentre Study About Its Incidence and Its Causes Perceived by Chronic Pain Patients. Patient Prefer Adherence. 2020;14:321-32.

27. Limandri BJ. Adverse Events, Drug Interactions, and Treatment Adherence. J Psychosoc Nurs Ment Health Serv. 2020;58:9-13.

28. Chandra IS, Kumar KL, Reddy MP, Reddy CM. Attitudes toward medication and reasons for non-compliance in patients with schizophrenia. Indian J Psychol Med. 2014;36:294-8.

29. Zhou J, Xiang YT, Li Q, Zhu X., Li W, et al. Gender differences in attitudes towards antipsychotic medications in patients with schizophrenia. Psychiatry Res. 2016;245:276-81.

30. Lange B, Mueller JK, Leweke FM, Bumb JM. How gender affects the pharmacotherapeutic approach to treating psychosis - a systematic review. Expert Opin Pharmacother. 2017;18:351-62.

31. Lauriello J, Perkins DO. Managing Transitions in Care and Adherence to Improve Outcomes in Schizophrenia. J Clin Psychiatry. 2019;80. pii: al18010wc1c. doi: 10.4088/JCP.al18010wc1c.

32. Chang JG, Roh D, Kim CH. Association between Therapeutic Alliance and Adherence in Outpatient Schizophrenia Patients. Clin Psychopharmacol Neurosci. 2019;17:273-8.

33. de Avila RCS, do Nascimento LG, Porto RLM, Fontenelle L, Filho ECM, et al. Level of insight in patients with obsessive-compulsive disorder: an exploratory comparative study between patients with "good insight" and "poor insight". Front Psychiatry. 2019;10:413.

34. Reddy YJ, Sundar AS, Narayanaswamy JC, Math SB. Clinical practice guidelines for obsessive-compulsive disorder. Indian $\mathbf{J}$ Psychiatry. 2017;59:S74-90.

35. Rozalski V, McKeegan GM. Insight and Symptom Severity in an Inpatient Psychiatric Sample. Psychiatr Q. 2019;90:339-50.

36. Suzuki M. Schizophrenia: What determines its clinical features and course? Psychiatry Clin Neurosci. 2019;73:99. 